\title{
Rhetoric and Visual
}

\section{Argument: proposition of methodological models based on the analysis of infographics}

\author{
Vanesca Carvalho LEAL (1) \\ Universidade Federal de Sergipe (UFS)
}

\section{○ \\ OPEN ACCESS \\ EDITED BY \\ - Isabel C. Michelan de Azevedo (UFS) \\ - Paulo R. Gonçalves-Segundo (USP) \\ - Fabrizio Macagno \\ (UNL) \\ REVIEWED BY \\ - Zilda Gaspar Oliveira de Aquino (USP) \\ - Márcia R. C. Pereira Mariano (UFS) \\ DATES \\ - Received: 09/30/2021 \\ - Accepted: 11/15/2021 \\ - Published: 12/07/2021 \\ HOW TO CITE \\ Leal, V. C. (2021). Rhetoric and Visual Argument: proposition of methodological models based on the analysis of infographics. Revista da Abralin, v. 20, n. 3 , p. 759-778, 2021.}

\section{ABSTRACT}

This study proposes analytic models for multimodal genres, specifically for the infographic, based on a finished master's research and in light of a brief literature review regarding multimodal argumentation. This study is justified by the fact that visual rhetoric is a relatively new field of investigation which still needs analytic proposals that promote the increase of studies in the area. This work, of a descriptive and qualitative nature, is grounded in theories and methodologies of the visual field (BLAIR, 2008; KJELDSEN, 2012; 2015; MATEUS, 2016; 2018; ROQUE, 2012; 2016; TSERONIS; FORCEVILLE, 2017; GONÇALVES-SEGUNDO, 2021; LEAL, 2021), and the gathering of data was based on Google Scholar through software Harzing's Publish or Perish. The results show that, even though the procedures have been developed for the analysis of infographics, the analytic method may collaborate with the growing studies in multimodal argumentation and may be applied to other genres circulating in society.

RESUMO

Este estudo propõe modelos de análise para gêneros compostos por multimodalidade, especificamente para o infográfico, com base em uma pesquisa concluída de Mestrado e à luz de uma breve revisão de literatura em torno da argumentação multimodal. Este estudo se justifica por ser a retórica visual um campo relativamente novo de investigação que carece de propostas analíticas que promovam o crescimento dos estudos na área. 


\section{REVISTA DA ABRALIN}

Este trabalho, de natureza descritiva e qualitativa, fundamenta-se em teorias e metodologias do campo visual (BLAIR, 2008; KJELDSEN, 2012; 2015; MATEUS, 2016; 2018; ROQUE, 2012; 2016; TSERONIS; FORCEVILLE, 2017; GONÇALVES-SEGUNDO, 2021; LEAL, 2021), e a coleta de dados teve por base o Google Scholar observado por meio do software de busca Harzing's Publish or Perish. Os resultados apontam que, embora os procedimentos tenham sido desenvolvidos para a análise de infográficos, o método analítico pode colaborar com os estudos da argumentação multimodal que se encontram em plena ascensão e pode ser aplicado a outros gêneros em circulação na sociedade.

\section{KEYWORDS}

Infographic. Methods of analysis. Multimodal argumentation.

PALAVRAS-CHAVE

Infográficos. Métodos de análise. Argumentação multimodal.

\section{Introduction}

The records made by primitive people through rupestrian art in caves and all of the other verbal and visual records kept throughout the centuries in the West indicate that there are different ways of articulating the verbal and non-verbal modalities when one wants to portrait or thematize issues related to daily life. Those representations confirm the social and communicative importance of images in setting ideas and motivated us to understand how images can have persuasive effects specially when they are associated with the discussion of themes that enable the confrontation of discursive positions.

Some illustrative scenes of persuasive use of images may be observed throughout history. The pictorial representations of great trials in Demosthenes's and Quintilian's age, for example, served to the intensification of emotions, as in Phryne's trial - one of the most famous courtesans in Athens in the 4 th century. She was prosecuted incurring the risk of death penalty, but after being practically presented naked, she received clemency and was acquitted due to her rare beauty being exposed before everyone, as the image provoked feelings of compassion in the audience (ALEXANDRE JÚNIOR, 2008). Pictorial representations used as decorations in great European cathedrals and in religious books in the Middle Age, which aimed at persuading the reader to follow religious guidance, were the tools used to keep the argument in the audience's mind, mostly due to a society composed of low educated citizens (BLAIR, 2008). 


\section{REVISTA DA ABRALIN}

In the context of a contemporary society, in order to promote the transmission of information in a fast, dynamic, and efficient way, the communicative spheres are composed of hybrid forms of presenting information. This is also reflected on the number of multimodal genres circling around "any text whose meanings are realized through more than one semiotic code" (KRESS; VAN LEEUWEN, 2006, p. 194) -, which may exercise argumentative functions, evoke desires/emotions, direct the understanding to the bias one wants to argue for, propagate or highlight certain perspectives, as may be observed in cartoons, memes, infographics, advertisements, among others.

The advantages of using visual resources with the objective of communicating something to the interlocutor in a fast and meaningful way lie in the evocative, realistic, and touching power that images may have, since it is possible to process a narrative with a higher number of images in a short period of time, unlike the same information conveyed in a printed or spoken form (BLAIR, 2008).

\footnotetext{
Recall the Coca Cola commercial shown during the 2002 Winter Olympics in Utah, in which an awkward youth wins the heart of an elegant female figure skater against the competition of several older handsome young men by giving her a Coke at the end of her program. The story is told with ingredients of poignancy, sexiness and humor-all in thirty seconds-and although (I would argue) this commercial is not an argument, it does illustrate the narrative capacity of the visual. (BLAIR, 2008, p. 51)
}

Even though image evoke this immediate power and may be used for convincing and persuading an audience, there is still some rejection to the idea that image may by itself generate an argumentative process (FLEMING, 1996; JOHNSON, 2003), since some authors understand that the argument must involve a logic syllogism in which there are two premises and one conclusion that justifies and proves the presented thesis in a clear and precise way. In addition to that, it is also said that arguments must have the power of refuting - a feature of words that images do not have, according to the cited authors. In this study, however, we assume that the rhetorical process that discursively occurs may be composed of linguistic and non-linguistic resources, verbal and visual ones, as Mateus (2018), among others, proposes.

In the scope of visual rhetoric, it is accepted that resources, either linguistic or visual, promote the communicative process. Nevertheless, for being a new investigation field, mostly in Brazil, it lacks specific methodologies, as Gonçalves-Segundo (2021) argues. Therefore, this study aims at presenting a model to analyze multimodal genres, specifically the infographics, based on a finished master's research and in light of a brief review of literature regarding multimodal argumentation.

In this study, one important issue for the analysis of multimodal argumentation is the infographic genre - a genre that "concentrates a greater and more diverse flux of verbal and visual elements in order to present information" (LEAL, 2021, p. 66). This genre is becoming more present in social contexts, being characterized for making a complex information clear through the simultaneous combination of verbal and visual resources. Besides, we believe that "the infographic may present a standpoint - a thesis or an argumentative question" (LEAL, 2021, p.61). This means that, even though the genre itself is not intended to convince in a clear way, it has an argumentative content to try to assure audience's adherence. 


\section{REVISTA DA ABRALIN}

This is a descriptive study based on a qualitative approach, grounded in visual argumentation theories (BLAIR, 2008; KJELDSEN, 2012; 2015; MATEUS, 2016; 2018; ROQUE, 2012; 2016; TSERONIS; FORCEVILLE, 2017), in methodological assumptions related to the visual field, such as GonçalvesSegundo (2021), and proposes an analysis of the infographic genre based on rhetoric-discursive categories as presented by Leal (2021).

Therefore, after the introduction, three sessions follow: the first exposes an overview of studies already carried out about rhetoric and visual argumentation; the second includes a systematic review of current studies that approach argumentation in multimodal genres and presents methodological models adopted in studies already done that may serve as foundations for future studies; finally, an illustrative analysis of the infographic text genre is developed in order to describe the argumentative functions that visual information may exercise.

\section{Overview of studies regarding rhetorical and visual argumentation}

Roland Barthes, the pioneer of image studies as a rhetoric source, describes how non-verbal elements articulate themselves in an advertising campaign to promote persuasive effects in relation to an audience. Although this description has contributed to the development of further studies and, thus, to the emergence of visual rhetoric as a filed (MATEUS, 2018), the main focus of the approach lied on how verbal and visual resources were articulated. That is why it can be said that these first approaches still belonged to the semiotic and communication fields (TSERONIS, 2018; FORCEVILLE, 2017).

In approximately more than fifty years, rhetorical theories have expanded in the sense of considering that the arguments may be expressed through verbal or visual resources because the central point is the success of the argumentation, "[...] as it may be attested in the robust production of the group $\mu$, at University of Liège, which since 1970 has been concerned with visual communication, [...] initially named Rhetorique gènèralisèe precisely for not privileging the verbal" (MOSCA, 1997, p. 24).

Ehninger, in 1972, present a concept of rhetoric that privileged non-linguistic symbols when involving artistic activities and architecture as persuasive symbols (MATEUS, 2016). In 1977, O'Keefe also defended the idea that the argumentation process encompasses the verbal and the visual because the author analyzes the argument as two different phenomena: (a) the product - which would be related to premises that support a conclusion; and (b) the process/argumentation - which involves a communicative and interactional act that seeks to defend and make a viewpoint accepted by a specific audience (TSERONIS; FORCEVILLE, 2017).

However, despite previous research done involving the study of more than one semiotic code in promoting rhetorical effects, it is in the late 1990's, more precisely in 1996, that the inaugural milestone of visual rhetoric is set through diverse publications, for example Logic, Art and Argument by Groarke; The possibility and actuality of visual arguments by Blair; The construction of claims in 


\section{REVISTA DA ABRALIN}

visual argumentation by Chryslee, Foss and Ranney, among others. In the following years, Hauser published Argumentation and advocacy on body argument and Catherine Palczewski made a speech about visual argumentation. In 2007, Birdsell and Groarke published a second especial edition that makes the discussion about visual rhetoric more consistent and mature, with the theme Outlines of a Theory of Visual Argument (KJELDSEN, 2015).

Twenty years after the inaugural milestone of visual rhetoric, Groarke published another especial edition about visual argumentation, presenting theories (Critical Theory, Rhetoric, Informal Logic, and Pragma-dialectics, among others) and disciplines (Social and Cognitive Psychology, Artificial Intelligence) that may contribute to the studies of the visual as an argumentative element (TSERONIS; FORCEVILLE, 2017).

Gonçalves-Segundo (2021) compares these theoretical perspectives that study visual argumentation by discussing the central focus of each theory, the main methodological apparatuses each perspective proposes and the dialogue with categories of analysis from semiotic theories. Fig. 1 below displays the comparison.

\begin{tabular}{|c|c|c|c|}
\hline & $\begin{array}{l}\text { Informal Logic } \\
\text { (Groarke) }\end{array}$ & Rhetoric (Kjeldsen) & $\begin{array}{l}\text { Pragma-dialectics } \\
\text { (Tseronis) }\end{array}$ \\
\hline Focus of research & $\begin{array}{l}\text { Examination of the di- } \\
\text { vision of work among } \\
\text { the modalities con- } \\
\text { cerning argumentative } \\
\text { structure and reason- } \\
\text { ing. }\end{array}$ & $\begin{array}{l}\text { Examination of the divi- } \\
\text { sion of work among the } \\
\text { modalities in relation to } \\
\text { the persuasive potential, } \\
\text { considering the symbolic } \\
\text { condensation process. }\end{array}$ & $\begin{array}{l}\text { Examination of the divi- } \\
\text { sion of work among the } \\
\text { modalities regarding its } \\
\text { role in the resolution of } \\
\text { a conflict of opinion. }\end{array}$ \\
\hline $\begin{array}{l}\text { Methodological ar- } \\
\text { senal }\end{array}$ & $\begin{array}{l}\text { Description and inter- } \\
\text { pretation of empirical } \\
\text { data from actual texts. } \\
\text { Even though it regards } \\
\text { how images are con- } \\
\text { strued, the focus seems } \\
\text { to remain on the in- } \\
\text { voked representation of } \\
\text { such modality. }\end{array}$ & $\begin{array}{l}\text { Description and inter- } \\
\text { pretation of empirical } \\
\text { data from actual texts. } \\
\text { The attention is drawn to } \\
\text { the invoked representa- } \\
\text { tion of images in relation } \\
\text { to the way they were de- } \\
\text { picted. Reception studies } \\
\text { have been valued and ap- } \\
\text { plied. }\end{array}$ & $\begin{array}{l}\text { Description and inter- } \\
\text { pretation of empirical } \\
\text { data from actual texts. } \\
\text { The attention is drawn } \\
\text { to the invoked repre- } \\
\text { sentation of images in } \\
\text { relation to the way they } \\
\text { were depicted. Quanti- } \\
\text { tative instruments of } \\
\text { analysis are valued. }\end{array}$ \\
\hline $\begin{array}{l}\text { Incorporation of } \\
\text { semiotic tools }\end{array}$ & $\begin{array}{l}\text { There is not a system- } \\
\text { atic incorporation of } \\
\text { categories of analysis } \\
\text { from semiotic frame- } \\
\text { works. }\end{array}$ & $\begin{array}{l}\text { The incorporation of an- } \\
\text { alytic tools from semiotic } \\
\text { framework is valued. }\end{array}$ & $\begin{array}{l}\text { There is a systematic } \\
\text { incorporation of cate- } \\
\text { gories of analysis from } \\
\text { Social Semiotics. }\end{array}$ \\
\hline
\end{tabular}

FIGURE 1 - Summary figure: multimodal argumentation 


\section{REVISTA DA ABRALIN}

Visual Rhetoric ${ }^{1}$ proposes, then, to distinguish the different semiotic sources that integrate themselves in a parallel way in order to construct arguments that enable the increment of adherence of a specific audience. These resources may be integrated to different symbolic apparatuses that are tied together in order to involve the audience in the communicative action (FOSS, 2008).

Visual resources expose information through condensed enthimemetic processes, i. e., visual acts with many implicit ideas that draws on the interlocutor's cognitive schemes construct the arguments (KJELDSEN, 2012). In the visual rhetoric field, the arguments are presented through mixed and/ or heterogeneous modes (BLAIR, 2008; BARCELÓ-ASPEITIA, 2012), in other words, visual arguments are those transmitted through a pictorial code or through a visual channel (ROQUE, 2012). Therefore, they may be perceived with or without the existence of verbal elements or through the parallel integration of all the elements, both linguistic or non-linguistic.

That being said, it is through the investigation of how verbal and visual elements are combined in the promotion of argumentative effects in empirical data that new developments - both in theory and in method - will emerge for the rhetorical analysis of multimodal genres. The next section will review some studies conducted in Brazil regarding multimodal argumentation.

\section{Systematic review: argumentation and multimodality}

The first studies of argumentation associated with images were carried out based on the advertising genre that by itself has the power to persuade ${ }^{2}$, and, frequently, to convince the interlocutor. Currently, advertising is the major field of research of visual rhetoric, however, there are studies being developed that encompasses argumentation in texts that do not specifically aim at persuasion or at convincing but may present an argumentative bias by defending a standpoint that one wants to be accepted.

Visual Rhetoric research is usually directed towards design and communication. In Linguistics, studies usually approach: multimodality as an instrument of argumentative organization of the text; the meanings conveyed by linguistic and enunciative resources in genres; argumentative strategies used in the production of videos; the relation between argumentation and cognitive linguistics in multimodal genres and in digital texts; the presence of multimodal argumentation in journalistic genres and in infographics, as research has recently observed (LEAL, 2021).

These thematic approaches were observed through a systematic review with the aim of understanding how the subject has been treated in the academic field. The mapping was done from August $2^{\text {nd }}$ to August $4^{\text {th }}$ in 2021 using the database Google Scholar with the help of Harzing's Publish or Perish version 7.30.3280.7752, a search software that extracts articles related to a given theme. The

\footnotetext{
${ }^{1}$ This paper adopts the term Visual Rhetoric. However, other studies adopt different terms such as multimodal rhetoric and/or multimodal argumentation, found, for example, in Tseronis and Froceville's (2017) study.

${ }^{2}$ According to Perelman and Olbrechts-Tyteca (2014, p.31), "we call persuasive an argumentation that is addressed to a particular audience and convincing one that should gain adherence of all rational beings".
} 


\section{REVISTA DA ABRALIN}

Portuguese keywords used were: "argumentação multimodal (multimodal argumentation)" and the aim of this mapping was "to guide the development of projects, indicating new routes to future investigations, and identifying what research methods have been used in one area" (SAMPAIO; MANCINI, 2007, p. 83).

In the selection of the studies, the following inclusion criteria were defined: (1) the publication has date equal or greater than the year $2015^{3}$; (2) selected publications having been published in peer reviewed journals of Linguistics; (3) the relevant title in relation to the studied object; (4) quality of the abstract; (5) studies with defined methods of analysis; (6) works that dealt with the analysis of one multimodal genre. Exclusion criteria were also established: (1) negation to inclusion criteria; and (2) being a duplicated version of the article.

With the systematic mapping, 964 articles were found. However, when applying the inclusion and exclusion criteria, 26 potential articles were found so as to be deeply read, but 20 articles were rejected since they did not fit all the established inclusion criteria, for not clearly presenting the methods of analysis and for not analyzing a specific multimodal genre, for example, and the others were selected because they fitted all the established criteria. The included studies contributed to the theoretical and methodological systematization of this study.

The article published by Roque (2016), Prolegômenos à análise da argumentação visual (Prolegomenon to argumentation analysis), is a great contribution to the studies of the visual in argumentation, since the author reopens previous discussions on two questions: "Do images tend to persuade or to convince?" and "Is visual argumentation possible?", presenting conditions to the analysis of these elements. To do so, the author analyzes the engraving La protesta by Leopoldo Méndez, exploring some topoi $i^{4}$ instead of others in the persuasion process. Therefore, the author defends the existence of visual argumentation, even if the starting point are theories of argumentation within language - as Anscombre and Ducrot (1988) propose. It also considers the general definition of discursive argumentation that aims at increasing the adherence of an audience to the theses defended in argumentation (PERELMAN, 1992 [1977]). It is worth noting that in previous studies, Roque (2012) had used the argumentative techniques proposed by Perelman and Olbrechts-Tyteca (2014) in analyses of advertising genres, posters, and anti-war photographs ${ }^{5}$.

Mateus, also in 2016, wrote an article that discusses the following question "Can the image be an argument?". The paper debates the persuasive purposes that images impose on society, discusses the role of images beyond a decorative function in verbal argumentation, and proposes that visual arguments have a discursive nature, derived from conclusions supported by reasons. From the

\footnotetext{
${ }^{3}$ In the survey conducted to produce our master's dissertation (LEAL, 2021), we had already made a systematic review in the online database from CAPES (Coordination for the Improvement of Higher Education Personnel) so as to observe the related works.

4 "[...] represent categories and relations that may work as heuristic models from which we may discover ways of approaching and speaking about the subjects" (GRÁCIO, 2013, Verbetes críticos da argumentação e retórica (Critical entries of argumentation and rhetoric).

${ }^{5}$ For more Information, see Roque $(2009 ; 2012)$.
} 


\section{REVISTA DA ABRALIN}

analysis of a cartoon, published by the newspaper "Expresso", in Portugal, the author concluded that "some visual images [...] may contain this argumentative nature which offer reasons (premises) that prove a conclusion" (MATEUS, 2016, p.16), but highlighted that not all images, by themselves, have argumentative structures.

In 2019, Gonçalves-Segundo and Isola-Lanzoni, in the article "Is the Earth flat?: an analysis of the articulation between epistemic argumentation, multimodality and scientific popularization in YouTube", approached how arguers supported a standpoint concerning the polemics about the shape of the planet by analyzing the role pictorial elements played in the construction of the argument. To do so, the authors analyzed the video "Is the Earth flat?" published by the YouTube channel Nostalgia under a rereading of Toulmin's (2006 [1958]) model as a productive source to investigate this process. One of the authors' conclusions was that the pictorial resources may serve as paraphrases of verbal resources. The researchers also suggested the need to intensify the studies in the area, mainly in contexts that discuss polemic themes already popularized.

Gonçalves-Segundo $(2020)^{6}$ also discussed the construction of multimodal metaphors and the pragmatic and rhetorical effects in practical argumentation, in the paper "Multimodal metaphors and practical argumentation: discussing rhetorical effects and modes of articulation between modalities". In order to do so, the author analyzed six governmental campaigns against Aedes aegypti, the mosquito behind the transmission of dengue fever and other diseases, using a corpus of about 50 multimodal texts. The main results obtained were: (1) the relevance of verbo-pictorial metaphors for the construction of negative consequences; and (2) the relevance of images in the construction of humor generated by the circumstances presented in the campaign, with the aim of attracting the readers' attention.

The texts written by Brito, Figueiredo and Santos Júnior $(2019 ; 2020)$ - Rhetoric, design, and multimodality: the construction of the ethos as a strategy of adherence in contemporary advertising"; Rhetoric and multimodality: visual design in focus, treat visual rhetoric as a fruitful field in contemporary studies due to the great presence of multimodal discourses in current society and also aim at finding out how a text composed of distinct modalities may increase the audience's adherence. In the studies, the authors analyzed videos produced by the supermarket company Edeka published in celebration dates, such as Christmas, using theoretical and methodological concepts of design - framing, angle, and composition of colors - and of rhetoric - the construction of ethos and the use of rhetorical figures. The researchers also explain that the videos may provoke rhetorical effects by arising emotions in the audience and by promoting the identification of the audience with the characters being presented, which contributes to the adherence of the audience to the presented ideas.

\footnotetext{
${ }^{6}$ More Information in chapter IV of the book Estudos de Linguagem, Argumentação e Discurso (Language, Argumentation, and Discourse studies) organized by Paulo Roberto Gonçalves-Segundo e Eduardo Lopes Piris (2021). This chapter was not considered in this systematic review, but it presents theoretical and methodological reviews used in multimodal argumentation analysis.
} 


\section{REVISTA DA ABRALIN}

This review allowed us to see that, although it is a new field of analysis, there are already some methodologies that serve as foundation for studies that aim at establishing a strategic interrelation between verbal and visual elements in the composition of an argumentative production.

\section{Methodological proposals}

Even though there are studies that discuss the relation between the verbal and the visual in the field of argumentation, the methods of analysis of roles and rhetoric values in multimodal genres may be considered insufficient in language studies. Due to a lack of consistent methods that may systematically direct an analysis, Kjeldsen (2015) indicates that there is a need to use theories based on the study of images and their representation, such as the The Grammar of Visual Design by Kress and Van Leeuwen (2006 [1996]), which discusses the representational, compositional, and interactive meanings that bring the reader and the text close to each other and contribute to communication.

From the identification of this methodological need, in this section, methodological models will be presented in order to serve future analysis that intend to articulate argumentation and multimodality. To so do, we decided to reunite studies that relate the verbal and the visual to rhetoric and to multimodal argumentation.

Gonçalves-Segundo (2021) proposes an analytical procedure that establishes a dialogue between Social Semiotics, Informal Logic, and Rhetoric to account for both (1) multimodal practical arguments and (2) multimodal epistemic arguments.

Practical argumentation concerns texts that contribute and helps the reader to make a decision and change a specific situation that is considered unacceptable. The author, then, uses governmental advertising campaigns that deal with the dangers of the spread of Aedes aegypti mosquito to illustrate how to operate with an argumentative scheme of this kind. Therefore, the researcher develops an abstract structure of the practical reasoning scheme that consists in: (a) a circumstantial premise or a situation that needs to be resolved; (b) goal premise - the future desirable situation; (c) a presumption - in face of a certain agent's action, the unacceptable situation may reach what was expected in the goal premise; and (d) a conclusion - the action that must be done (GONÇALVESSEGUNDO, 2021). Thus, the author applies this scheme in the analyzed campaign, as in figure 2. 


\section{REVISTA DA ABRALIN}

\section{Practical Reasoning Scheme}

Circumstantial Premise (Problem): The current situation of high contamination by dengue fever is undesirable/unacceptable.

Objective Premise (End): Reaching a state of affairs in which infections by dengue fever are minimal or null is desirable.

Means-End Premise (Presumption): (Presumably) eliminating the foci of reproduction of Aedes aegypti will reverse the problem of current contamination and will reach to the state of affairs in which the infections by dengue fever are minimized or, ideally, eliminated.

Conclusion (Means/ Proposal of Action): Population must eliminate the foci of reproduction foci of Aedes aegypti.

FIGURE 2 - Practical Reasoning Scheme

Source: Content adapted to English, based on Gonçalves-Segundo (2021, p. 91)

The epistemic multimodal arguments through enthymematic schemes construed from two posts extracted from Facebook: both criticize the evidences given by the other party in the defense of their respective theses: the sphericity $\mathrm{x}$ the flatness of the Earth. Thus, as in the previous case, the author makes an interpretive discussion of the results, construes the relevant argumentation schemes, and reflects about the role of the argument from perception in the polemics, presenting qualifications about the use of this scheme.

Another methodological analysis of verbal and visual resources that articulates rhetoric and multimodality through an interpretive-discursive discussion of premises, justifications, genre composition, and argumentative technique is Leal's (2021) dissertation ${ }^{7}$. In her study, the researcher proposes a method of analysis that contributes to understanding the rhetorical-argumentative roles and values of verbal and visual resources in ${ }^{\text {the }}$ nfographic genre. For that, the author makes a textual discursive analysis ${ }^{8}$ of that multimodal genre, highlighting the structure, the composition, and the organization in accordance with the compositional characteristics and the semiotic elements presented, such as the font, the chromatic constitution, the interrelation of the visual and the verbal elements, etc., through two frames that contemplate: (1) cues of visual production; and (2) cues of verbal production, as demonstrated in figure 3.

\footnotetext{
${ }^{7}$ It is worth noting that this work has been already forwarded and authorized for online publication, but it has not been published in the Federal University of Sergipe Institutional Repository.

${ }^{8}$ This kind of analysis goes through three processes: unitarization of compositional elements, categorization of these elements, and production of metatext - interpretation of the analyzed data (MEDEIROS; AMORIM, 2017; MORAES; GALIAZZI, 2006).
} 


\section{REVISTA DA ABRALIN}

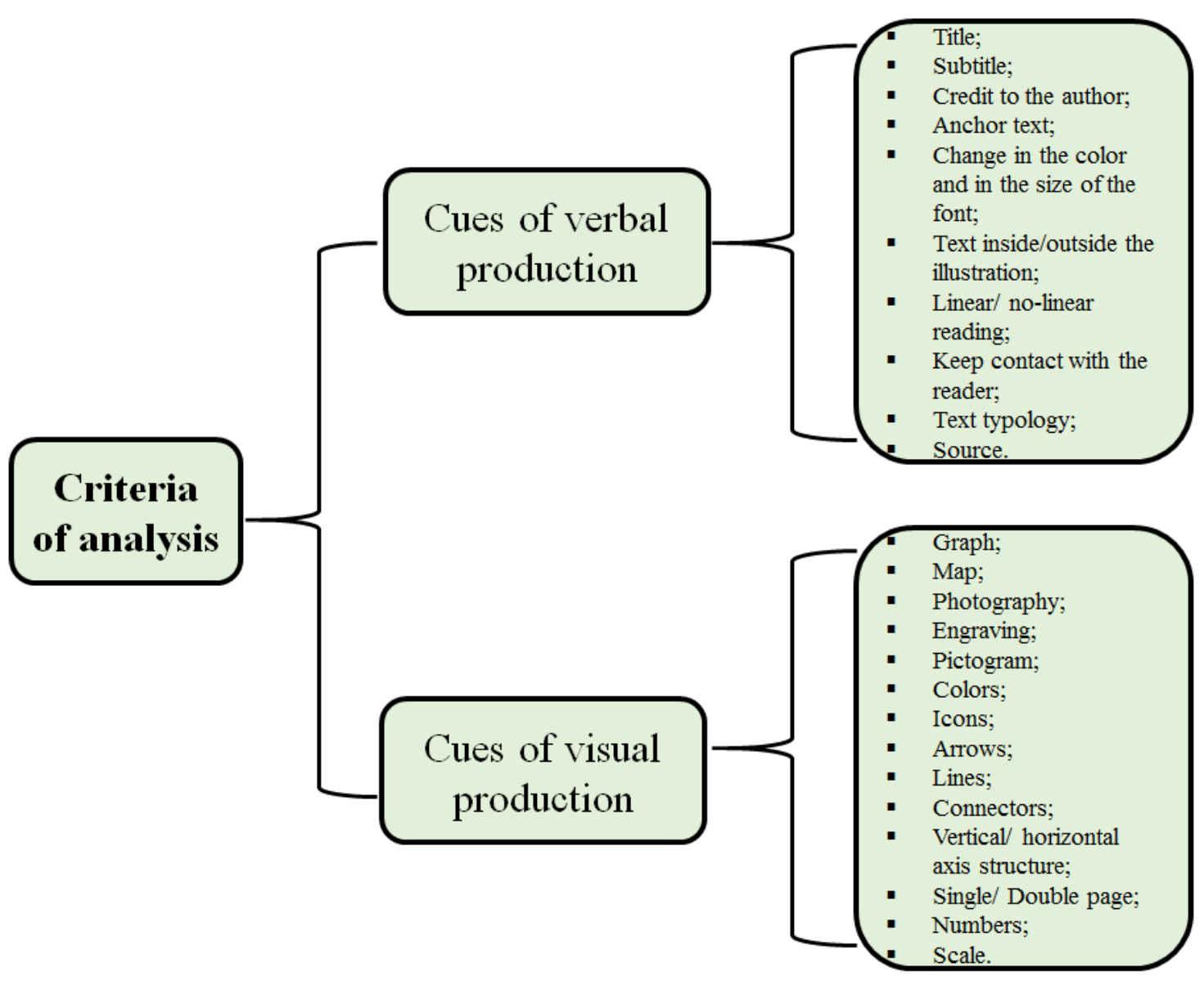

FIGURE 3 - Criteria of compositional technical analysis of verbal-visual resources in infographics Source: Own elaboration, from Leal (2021, p. 72-73)

Those criteria of analysis were developed from the observation of the characteristics presented in the categories of infographics adopted by Fogolari (2009) as well as from the identification of the components present in the research corpus. These verbal-visual clues served as basis for the analysis of the infographic and may be used in the analysis of other genres composed of multimodality. It is worth noting that besides the analysis of compositional resources, argumentative techniques present in the genre were also described based on Perelman and Olbrechts-Tyteca's (2014) New Rhetoric for the construction of a thorough and interpretive analysis and for the metatext production. 


\section{Ilustrative analysis: infographic "How did the scheme of message spread in WhatsApp work?"}

Brazilian 2018 elections were marked by the spread of questionable information by foreign marketing companies in social media. The infographic (figure 4) succinctly portraits how the process of mass dissemination of these messages in WhatsApp occurs. This is done through a description of how the contact lists to which the messages were forwarded were built and segmented, a demonstration of the reach prediction generated by each message, and a presentation of the resources that serve as protection to users' data, and of the resources that can be monitored.

The text that accompanies the infographic in the newspaper presents WhatsApp as an application that has the purpose of facilitating communication, enabling users to exchange instant messages and make calls without charge. Nevertheless, it became a machine that disseminates rumors, hate feelings, disinformation, and fake news. The app, then, stopped being a social tool and turned into a trading tool, used by politicians and the government, resulting in a new campaign format, both in relation to the advertising and to the dissemination of news.

In addition to that, the text presents measures that could be used to combat this activity, such as the reduction of the number of participants in each group to only five people, as is already the case in India. However, in Brazil, the opposite happened, the number increased from 50 to 250 participants per group. This "ease" jeopardizes users' privacy and makes Brazil a laboratory of tests of politics of technologies because the damage caused will rarely be predicted. Therefore, it is possible to infer a discursive relation between the news published in the newspaper and the infographic, since its goal is to describe and to explain how the spreading of messages via application works through argumentative resources that may convince and persuade the reader of the importance of spreading trustworthy information to inform the population.

\footnotetext{
${ }^{9}$ The infographic is part of the corpus of a study entitled "Analysis of the genre infographic in the digital newspaper Folha de São Paulo under the assumptions of visual rhetoric".
} 


\section{REVISTA DA ABRALIN}

How did the scheme of message

spread in Whatsapp work?

1. Illegal lists

From cellphone lists illegally provided by charging

companies or employers of telephone companies,

the marketing agencies set groups and Whats App

boadcast lists. These lists enable the segmentation,

among other criteria, into: region, gender, age, income.

$$
\text { (5) }
$$

Region Genre Age Income

2 . Segmentation of the content

With specific lists for each segment of the

electorate, the agencies are able to send

content created for each audience. Examples:

\begin{tabular}{|c|c|c|}
\hline $\begin{array}{r}\text { Conten } \\
\text { about fam }\end{array}$ & $\begin{array}{l}\text { Criticism of } \\
\text { social-welfare }\end{array}$ & viole \\
\hline & $\downarrow$ & $\downarrow$ \\
\hline $\begin{array}{l}\text { er or relig } \\
\text { voters }\end{array}$ & $\begin{array}{l}\text { urban } \\
\text { elect }\end{array}$ & \\
\hline
\end{tabular}

3. It is impossible to know the exact reach of the dissemination

In July, WhatsApp defined the limits to the

forwarding of messages in Brazil.

However, in order to circumvent the limitation, the agencies

use SIM cards from other countries.

How it was supposed

to work in Brazil

ince July, cellphone numbers SIM cards registered in other

may forward message

countries, as the USA and Argentina,

in WhatsApp for the maximum

of 20 conversations

are able to forward

ne message up to

250 conversations.

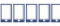

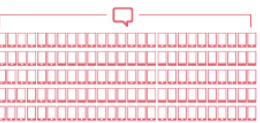

Considering the maximum of $\mathbf{2 5 6}$ users per group, it is possible to reach.

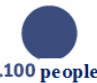

63.750 people

4. The cryptography does not allow to monitor the content

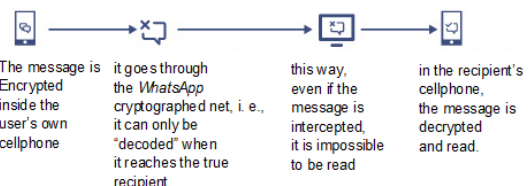

5 . What is possible to be monitored after all?

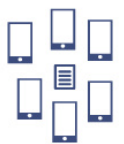

Whatsapp has

metadata i.e.

literally data

Source: WhatsApp and TSE

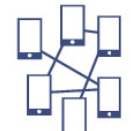

The company knows which

users (cellphone numbers)
talk to each other, in which

roups they participate, how man

messages they send, and in which

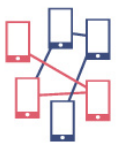

rom these data WhatsApp search

for uncommon

pattems of use

that practice spam 


\section{REVISTA DA ABRALIN}

In the analysis of the infographic, we observed that 18 technical compositional criteria serve as clues of verbal production and of visual production. Although a bit long, the title is straightforward and allows inferring the infographic's theme as well as stablishing the keywords that define the topic, such as, scheme, message spreading, social network, and WhatsApp.

The infographic has explicative as well as descriptive characteristics of the functioning of the scheme of messages. It is organized in a vertical axis, on a single page, and divided into five numbered parts that provoke a certain linearity in the reading, since the reader is likely to follow the steps determined by the sequence and "can only obtain a view of the whole after reading its parts" (LIMA, 2015, p.118). It is worth noting that these numbered parts are highlighted through the use of bold font in "bold" in order to attract the reader's attention; the text is written outside the illustrations; and there are some clues of visual production, such as: graph, map, colors - blue and red, icon, arrows, connectors, among other elements that contribute to the argumentative construction.

The starting point of the argumentation is established by the arguer's assumption that the audience, to whom the speech is directed, has previous knowledge of the fact exposed in the text - the spread of messages in WhatsApp, used as a campaign element in 2018 elections. This is possible as this topic was frequently discussed in social media, television, print and digital news, as well as in other means of mass communication, which defended the non-veracity of the information conveyed in those messages.

In order to introduce the idea of non-veracity of the facts, the arguer presents how the marketing agencies select users, profiles, and information that they would spread. This means that they make a choice, make a decision in relation to the bias that the content will have and to whom it will be transmitted, as, for example, the region the users live, the gender they belong to; their age and their income.

The arguer highlights that this segmentation is "illegally" built and that the contents are "created' for each audience" (emphasis added): older or more religious voters receive content about family; voters that belong to urban areas and have higher purchase power receive criticism of social welfare programs; female voters receive content about the combat of violence against women.

Thus, by making a choice, be it in the selection of content, of the targeted group, or of the way they organize themselves, informational harm is done to the population. It, then, starts to defend and follow these ideas without any critical thinking. This may happen due to a generated "communion" with the audience since there is disposition to listen to or read a speech that took into account the characteristics of the recipients' environment, and their social and cultural affiliations (PERELMAN; OLBRECHTS-TYTECA, 2014).

In face of this construal, the following questions emerge: Can the spread messages be considered trustworthy? Are there alternatives that may be used to monitor the content that has been spread among users? Would the cryptography of the messages be a positive or negative resource in this context? 


\section{REVISTA DA ABRALIN}

Therefore, it is possible to indicate that the argumentation starts through an agreement about the real and through this agreement; the following scheme of practical reasoning is established:

\begin{tabular}{|l|l|}
\hline \multicolumn{2}{|c|}{ Practical Reasoning Scheme } \\
\hline $\begin{array}{l}\text { Circumstantial Premise } \\
\text { (Problem) }\end{array}$ & $\begin{array}{l}\text { Schemes of mass spread of WhatsApp messages are being } \\
\text { carried out in Brazil. }\end{array}$ \\
\hline Goal Premise (End) & $\begin{array}{l}\text { Reaching a communication through social media that } \\
\text { enables people to access trustworthy informational content } \\
\text { is desirable. }\end{array}$ \\
\hline $\begin{array}{l}\text { Means-End Premise } \\
\text { (Presumption) }\end{array}$ & $\begin{array}{l}\text { (Presumably) to reverse the scheme of mass spread of } \\
\text { messages in WhatsApp and to enable the population to } \\
\text { access trustworthy information, it is necessary to identify } \\
\text { the messages with false content before reaching the } \\
\text { recipients. }\end{array}$ \\
\hline $\begin{array}{l}\text { Conclusion (Means } \\
\text { Claim for Action) }\end{array}$ & $\begin{array}{l}\text { Telephone companies in Brazil should limit the number of } \\
\text { messages that may be forwarded to users of WhatsApp } \\
\text { social network and monitor the broadcast content. }\end{array}$ \\
\hline
\end{tabular}

FIGURE 5 - Practical reasoning scheme from the infographic: How did the scheme of message spread in WhatsApp work? Source: Own elaboration, adapted from the scheme proposed by Gonçalves-Segundo (2021)

This scheme of practical reasoning was developed through the interrelation between verbal and visual resources present in the infographic. One remarkable aspect is the use of the "locus of the preferable", specially of "quantity", as it is possible to infer that, the more the messages will be spread, the less the population will access trustworthy knowledge, since they contain unreliable information. It, may, thus, generate a lasting evil (PERELMAN; OLBRECHTS-TYTECA, 2014).

This reference to quantity is supported by the "figure of repetition". Two visual elements are repeated. The first one is a sort of icon (cellphones and speech balloons) that represents how the functioning of the messages in Brazil (represented by a map) should be - each user forwards the same message to the maximum number of 20 users - as well as how the registers of SIM cards outside the country works; for example, in the United States and Argentina - each user has the possibility to forward up to 250 conversations. The second visual element that presents a repetition is the graph: similar images are reiterated, with different numerical representations, to promote the reinforcement of quantitative content (FIORIN, 2019), as it can be seen in Figure 5: 


\section{REVISTA DA ABRALIN}

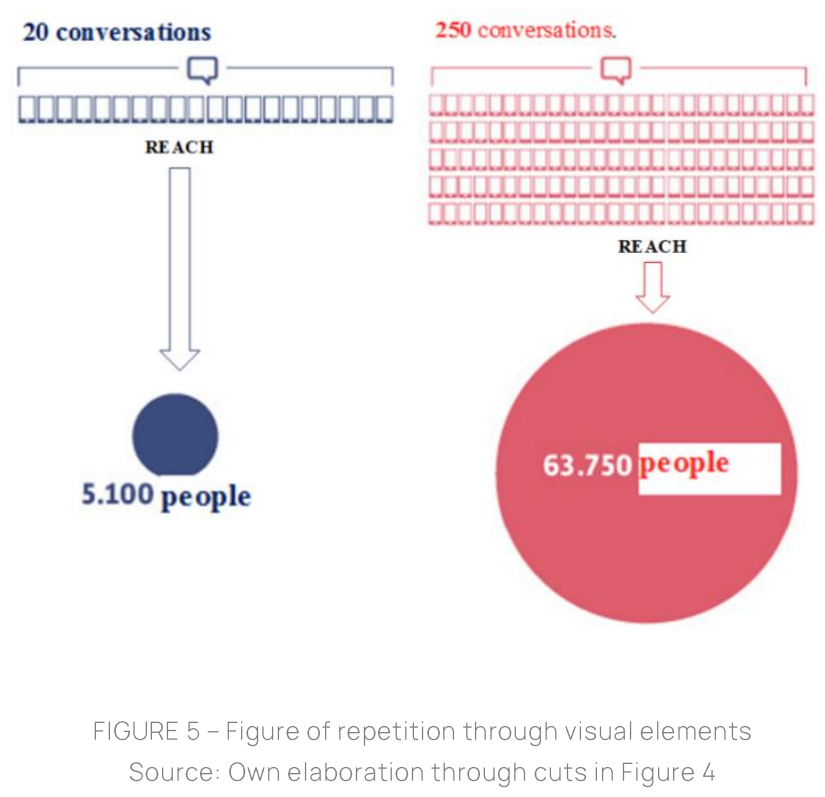

The repetition has a rhetorical value, since it visually reinforces the quantitative idea of the number of messages that reaches users according to the possibilities of each country's SIM card. A "probability" argument may also be inferred from this construal, since it can be assumed that the information may reach a higher number of people, if the number of conversations that may be forwarded increases, either in Brazil or in other countries.

After showing numerical data concerning the spread and how it happens, the arguer presents a sequence of icons with captions that describe how messages are sent from the sender's device to the recipient's. In this process, there is an essential element that promotes and establishes safety, confidentiality, and the identification of the data - the "cryptography". The message that comes from the sender and reaches the recipient is impossible to be read midway even by the application itself.

This way, an "incompatibility" is generated because even though it protects the integrity of the data, providing more safety to the user, it promotes the explosion of false messages that may freely circulate without the possibility of monitoring and/or preventing the dissemination of their content. In this case, an attitude "that rethinks its meanings and its rules conforming to real situations and indispensable decisions to its action" should be taken (PERELMAN; OLBRECHTS-TYTECA, 2014, p. 225).

In the last part of the infographic (part 5), three images with explicative legends are presented. The first one presents an icon of a message in the center, surrounded by icons of cellphone devices positioned in an independent way in the second one, next, the devices are united by connectors; finally, in the third one, the same previous image is displayed but with the colors of the devices and connectors interpolated in blue and read.

Initially, "the use of the colors could be disregarded because they are indicative of the 'pattern' or the 'style' of the newspaper in the analyzed corpus, the majority displays blue, red, and gray, thus, not having rhetorical value" (LEAL, 2021, p. 90). Nevertheless, it is possible to observe a meaning effect provoked by the use of those colors - red, for example, is often related to danger, to a request for attention, or to the goal of interrupting some action. In the case of the infographic, it could 


\section{REVISTA DA ABRALIN}

represent the danger in relation to the high number of users reached through SIM cards from other countries that spread fake news, promoting, then, negative effects in the dissemination of information, and also demonstrates an alert to what it possible to be monitored, i. e., the irregular patterns of WhatsApp usage.

It is interesting to note that this is the only part that contains a direct question - "What is possible to be monitored after all?". A possible interpretation is that the reader, when realizing the difficulties of monitoring the messages that are distributed, have aversion to the situation and, at the same time, the concern with understanding and identifying if a proposal of action that may prevent the dissemination of information is possible. These visual elements represent the metadata that WhatsApp has and show to what exactly the company has access, such as: phone number of users, which numbers connected to the other, how many messages and at what time they were sent from each device, among others. Therefore, the application can establish usage patterns and, at some point, may spot who practices spam.

Through the analysis we observe that infographics, as a genre, may not directly establish a disposition of convincing and persuading the audience, but in a way, it guides the reader to follow the arguer's practical reasoning through the use of resources that compose, structure, explain and describe the theme of the infographic - which was to establish the proposals that may prevent the spread of false information, so that trustworthy content that truly inform the population be shared.

\section{Final remarks}

This study aimed at making a short review of literature regarding multimodal argumentation in order to contextualize a discussion about the pictorial elements that may be analyzed when considering one of the genres that frequently circulate in contemporary society: the infographic.

The systematic review of literature revealed that advertising has been privileged in the analyses that consider the relations between the verbal and the visual in the composition of multimodal discourses. However, we identified that other genres may also be studied when observing the way that the resources are articulated in the setting of an argumentation, which is the case of the infographic genre.

In order to present a model of analysis of infographics, the study drew on concepts derived from the new rhetoric and on insights from Gonçalves-Segundo's (2021) discussion on practical argumentation, especially his reconfiguration of the practical reasoning scheme, and from Leal's (2021) analytical model. The latter proposal establishes a set of cues of verbal production and of visual production that help understanding the rhetorical-argumentative roles that the verbal and visual elements play in a given genre and the values associated with these selections.

From the analysis of the infographic "How did the scheme of message spread in WhatsApp work?", it was possible to understand that the title, the anchor text, the change in the color of the font, the text written outside the illustrative elements, and the linear reading were elements that characterize the genre considered as a descriptive-explicative type of utterance, and that promote 


\section{REVISTA DA ABRALIN}

the development of an argumentative path. In relation to visual aspects, we noted that the graph, the colors, the icons, the arrows, the connectors, the vertical axis, the single page, and the numbers not only guide the reader, but also promote the composition of figures and argumentative reasoning.

We also concluded that a previous agreement with the reader is established through the articulation between verbal and visual elements so that it is possible to discuss the mass spread of messages through applications. A relevant argumentative strategy for doing so is the locus of quantity since the greater the quantity of forwarded messages is, the greater will be the acceptation of the information that is being spread. In addition to that, the infographic exposes a figure of repetition through the iconic elements and graphs aiming at reinforcing the comparison, providing the audience with a striking probability of increase in these quantities.

From this study, we observed that the field of multimodal argumentation, even being new and with a few defined methods, is growing due to its communicative importance and to the impact that visual symbols has been causing on society for a very long time. Even with the prevalence of studies that analyze verbal arguments, this research presented theoretical discussions and analytical models that take multimodal genres into account, restating that there is no hierarchy between linguistic and non-linguistic elements; on the contrary, their articulation allows the composition of complementary roles and argumentative values, mostly the infographic.

We hope that the reviewed theories and studies reunited in this article may contribute to the widening of analytic methods as well as to the discussions concerning the possibilities of argumentative compositions of multimodal genres.

\section{REFERENCES}

ALEXANDRE JÚNIOR, M. Eficácia Retórica: A palavra e a imagem. Revista Rêthorikê - Revista Digital de Retórica, Centro de Estudos Clássicos, Universidade da Beira Interior. Mar. 2008. Disponível em: https://bit.ly/33Qdhlp. Acesso em: 05 set. 2019.

BARCELÓ-ASPEITIA, A. A. Words and Images in Argumentation. Argumentation, México, v.26, n.3, p.355-368, 24 nov. 2012. Disponível em: https://bit.ly/3dCCV1q. Acesso em: 18 jun. 2019.

BLAIR, J. A. The Rhetoric of Visual Arguments. In: HILL, C. A.; HELMERS, M. (org.). Defining visual rethorics. London: Lawrence Erlbaum Associates, 2008. p. 41-61. Disponível em: https://bit.ly/2UszR0q. Acesso em: 16 jun. 2019.

BRITO, G. A. de; SANTOS JUNIOR, V. F.; FIGUEIREDO, M. F. Retórica, design e multimodalidade: a construção do ethos como estratégia de adesão no discurso publicitário contemporâneo. EIDEA - Revista Eletrônica de Estudos Integrados em Discurso e Argumentação, Ilhéus, v.2, n.19, p.54-70, dez. 2019. Disponível em: https://bit.ly/3zRAK4S. Acesso em: 04 ago. 2021.

BRITO, G. A. de; SANTOS JUNIOR, V. F.; FIGUEIREDO, M. F. Retórica e multimodalidade: a composição visual em foco. Revista (Con)Textos Linguísticos, Vitória, v. 14, n. 27, p. 194-214, 2020. Disponível em:

https://bit.ly/3l3WRyP. Acesso em: 04 ago. 2021. 


\section{REVISTA DA ABRALIN}

FIORIN, J. L. Figuras de retórica. São Paulo: Contexto, 2019.

FLEMING, D. Can pictures be arguments? Argumentation and Advocacy, Texas Tech University, v. 33, n.1, p. 11-22, Summer, 1996. Disponível em: https://bit.ly/2JjLvnO. Acesso em: 08 jun. 2019.

FOGOLARI, L. A. O Gênero infográfico: Uma análise sociorretórica. Dissertação (Mestrado em Ciências da Linguagem) - Universidade do Sul de Santa Catarina, Tubarão, 2009. Disponível em: https://www.riuni.unisul.br/handle/12345/4596. Acesso em: 04 mai. 2019.

FOSS, S. K. Framing the study of visual rhetoric: Toward a transformation of rhetorical theory. In: HILL, C. A.; HELMERS, M. (org.). Defining visual rethorics. London: Lawrence Erlbaum Associates, 2008. p. 303-313. Disponível em: https://bit.ly/39pzSq5. Acesso em: 16 jun. 2019.

GONÇALVES-SEGUNDO, P. R.; ISOLA-LANZONI, G. A Terra é plana?: uma análise da articulação entre argumentação epistêmica, multimodalidade e popularização científica no Youtube. REDIS: Revista de estudos do discurso, no 8, p. 84-121, ano 2019. Disponível em: https://bit.ly/3yP6xlB. Acesso em: 02 ago. 2021.

GONÇALVES-SEGUNDO, P. R. Multimodal metaphors and practical argumentation:

discussing rhetorical effects and modes of articulation between modalities. Revista de Estudos da Linguagem, Belo Horizonte, v. 28, n. 2, p. 801-844, 2020. Disponível em: https://bit.ly/3yVJsxO. Acesso em: 02 ago. 2021.

GONÇALVES-SEGUNDO, P. R. Argumentação multimodal: múltiplos olhares para um objeto complexo. In: GONÇALVES-SEGUNDO, P. R.; PIRES, E. L. Estudos de Linguagem, Argumentação e Discurso. Campinas, SP: Pontes Editores, 2021, p. 73-109.

GRÁCIO, A. R. Verbetes críticos da argumentação e retórica. CAR - Casa da Argumentação e da Retórica, Coimbra: Grácio Editor/Instituto de Filosofia da Linguagem da Universidade Nacional de Lisboa, 2013. Disponível em: https://bit.ly/2CugOMD. Acesso em: 12 de set. 2021.

JOHNSON, R. Why “visual arguments" aren't arguments. In: V Ontario Society of Argumentation Studies Conference (OSSA), 5, 2003, Canada. Annals [...]. Ontário: OSSA, 2003. p.1-13. Disponível em: https://bit.ly/2Yz3sal. Acesso em: 20 nov. 2019.

KJELDSEN, J. E. Pictorial Argumentation in Advertising: Visual Tropes and Figures as a Way of Creating Visual Argumentation. In: VAN EEMEREN, F. H.; GARSSEN, B. (ed.). Topical Themes in Argumentation Theory: Twenty Exploratory Studies. Amsterdam: Springer Netherlands, 2012. p. 239-255. Disponível em: https://bit.ly/312mGa7. Acesso em: 12 jan. 2020.

KJELDSEN, J. E. The Study of Visual and Multimodal Argumentation. Argumentation, v. 29, n 2, p. 115-132, maio 2015. Disponível em: https://bit.ly/2wB4eZv. Acesso em: 12 jun. 2019.

KRESS, G. R.; VAN LEEUWEN, T. Reading images: the grammar of visual design. 2. ed. London and New York: Routledge, 2006 [1996]. Disponível em: https://tinyurl.com/y5yrrlqu. Acesso em: 15 jun. 2019.

LEAL, V. C. Análise do gênero infográfico no Jornal Digital Folha de São Paulo com base nos pressupostos da retórica visual. 2021. Dissertação (Mestrado em Letras) - Universidade Federal de Sergipe, São Cristóvão, 2021. No prelo.

LIMA, R. C. O que é infografia jornalística? Revista InfoDesign - Revista Brasileira de Design da Informação, São Paulo, v.12, n.1, p.111-127, 2015. Disponível em:

https://www.infodesign.org.br/infodesign/article/download/312/219. Acesso em: 21 jun. 2019.

MATEUS, S. Pode uma imagem ser um argumento? Revista Famecos - mídia, cultura e tecnologia, Porto Alegre, v. 23, n. 2, maio/jun./jul./ago. 2016. Disponível em: https://bit.ly/2Jl2hCS. Acesso em: 27 ago. 2019. 


\section{REVISTA DA ABRALIN}

MATEUS, S. Introdução à retórica no séc. XXI. Covilhã: Editora LabCom.IFP - Universidade da Beira Interior, 2018. Disponível em: https://bit.ly/39nhWMF. Acesso em: 26 out. 2019.

MEDEIROS, E. A. de; AMORIM, G. C. C. Análise textual discursiva: dispositivo analítico de dados qualitativos para a pesquisa em educação. Laplage em Revista, Sorocaba, v.3, n.3, p.247-260, set. /dez. 2017. Disponível em: https://bit.ly/2LjaT13. Acesso em: 20 dez. 2020.

MORAES, R.; GALIAZZI, M. do C. Análise textual discursiva: Processo reconstrutivo de múltiplas faces. Revista Ciência e Educação, v.12, n.1, p.117-128, 2006. Disponível em: https://bit.ly/38MTear. Acesso em: 02 dez. 2019.

MOSCA, L. S. Velhas e novas retóricas: convergências e desdobramentos. In: MOSCA, L. S. (org.). Retóricas de ontem e de hoje. São Paulo: Humanitas, 1997, p.17-54. Disponível em: https://bit.ly/3dHBwqz. Acesso em: 21 ago. 2019.

O'KEEFE, D. Two concepts of argument. Journal of the American Forensic Association, v. 8, n. 3, p. 121-128, Winter, 1977. Disponível em: https://bit.ly/39u7Jhw. Acesso em: 14 jun. 2019.

PERELMAN, C. O império retórico. Tradução: Fernando Trindade e Rui Alexandre Grácio. Edições ASA: Porto, 1992 [1977].

PERELMAN, C.; OLBRECHTS-TYTECA, L. Tratado da argumentação: A Nova Retórica. São Paulo: Editora WMF Martins Fontes, 2014

ROQUE, G. Visual argumentation. A further reappraisal. In: VAN EEMEREN, F. H.; GARSSEN, B. (ed.). Topical themes in argumentation theory: Twenty exploratory studies. Dordrecht: Springer, 2012. p. 1720-1734. Disponível em: https://bit.ly/3d9eTcL. Acesso em: 07 jun. 2019.

ROQUE, G. Prolegômenos à análise da argumentação visual. EIDEA - Revista Eletrônica de Estudos Integrados em Discurso e Argumentação, Ilhéus, n.12, p.234-254, jul./dez. 2016. Disponível em: https://doi.galoa.com.br/doi/10.17648/eidea-12-1327. Acesso em: 02 maio 2019.

SAMPAIO R. F.; MANCINI, M. C. Estudos de revisão sistemática: Uma guia para síntese criteriosa da evidência científica. Revista Brasileira de Fisioterapia, São Carlos, v.11, n.1, p.83-89, jan./fev. 2007. Disponível em: https://bit.ly/3iiBvf9 . Acesso em: 01 maio 2019.

TSERONIS, A.; FORCEVILLE, C. The argumentative relevance of visual and multimodal antithesis in Frederick Wiseman's documentaries. In: TSERONIS, A.; FORCEVILLE, C. (ed.). Multimodal Argumentation and Rhetoric in Media Genres. Amsterdam: John Benjamins, 2017. p. 165-188. Disponível em: https://bit.ly/3fy46KN. Acesso em: 20 fev. 2020. 